\title{
Do current European lake monitoring programmes reliably estimate phytoplankton community changes?
}

\author{
Victoria Bergkemper (iD) Thomas Weisse
}

Received: 14 May 2017/Revised: 17 October 2017/Accepted: 30 October 2017/Published online: 15 November 2017

(C) The Author(s) 2017. This article is an open access publication

\begin{abstract}
Many European lakes are monitored according to the EU Water Framework Directive (WFD), with focus on phytoplankton biomass and species composition. However, the low-frequency WFD monitoring may miss short-term phytoplankton changes. This is an important issue because short-term extreme meteorological events (heat waves and heavy rain) are predicted to increase in frequency and intensity with climate change. We used records from Lake Mondsee (Austria) from 2009 to 2015 to test if a reduction from monthly to seasonal sampling affected the average annual phytoplankton biovolume. Furthermore, we combined inverted light microscopy, FlowCAM and flow cytometry to estimate the effect of sampling during extreme events on average phytoplankton biovolume. Relative to monthly sampling, seasonal sampling significantly overestimated phytoplankton biomass. A heat wave in 2015 and two
\end{abstract}

Guest editors: Nico Salmaso, Orlane Anneville, Dietmar Straile \& Pierluigi Viaroli / Large and deep perialpine lakes: ecological functions and resource management

Electronic supplementary material The online version of this article (https://doi.org/10.1007/s10750-017-3426-6) contains supplementary material, which is available to authorized users.

V. Bergkemper $(\bowtie) \cdot$ T. Weisse

Research Department for Limnology, University of Innsbruck, Mondseestraße 9, 5310 Mondsee, Austria e-mail: Victoria.Bergkemper@gmx.de episodes of heavy rain in 2015 and 2016 caused species-specific changes; biovolumes of chlorophytes and the filamentous cyanobacterium Planktothrix rubescens (De Candolle ex Gomont) Anagnostidis \& Komárek increased significantly during the heat wave. Using live material with FlowCAM and flow cytometry, we detected small and fragile cells and colonies that were either ignored or underrepresented by analysing fixed samples with light microscopy. We suggest a modified sampling and analysis strategy to capture short-term changes within the phytoplankton community.

Keywords Water Framework Directive .

FlowCAM · Flow cytometry · Lake Mondsee

\section{Introduction}

Phytoplankton plays a key role at the base of pelagic food webs and its biomass and species composition are directly related to the trophic state of water bodies. Therefore, phytoplankton is one of the four biological quality elements used for the assessment of the ecological status of European surface waters according to the European Union Directive 2000/60/EC (EC, 2000) better known as Water Framework Directive (WFD). The primary aims of the WFD are the maintenance and recovery of water quality and to 
ensure good surface and groundwater status by 2027 at the latest (Arle et al., 2016). The WFD requires that phytoplankton species composition, abundance and biomass are measured to assess the ecological status of lakes. Additionally, most EU countries use assessment procedures that evaluate phytoplankton taxa in relation to nutrient conditions. In Austria, several metrics are calculated, i.e. phytoplankton biovolume, Chlorophyll a concentrations and a modified Brettum Index; (Brettum, 1989; Dokulil et al., 2005; Wolfram et al., 2015), which eventually result in the 'Ecological Quality Ratio' [EQR; (van de Bund \& Solimini 2007)]. The EQR is constrained to values ranging from zero (the worst possible status) to 1 (excellent) and evaluates the current ecological status relative to a reference condition, i.e. an undisturbed, quasi-pristine status for the respective water body. The 'normalised Ecological quality ratio' (nEQR) is the mean value of the metric converted to a normalised EQR scale, where the classes are equally spaced (e.g. the boundary value between moderate and good status is always 0.6 and the boundary value between good and high status is always 0.8) (http://dd.eionet.europa.eu/ dataelements/latest/resultNormalisedEQRValue).

The EU member states are requested by the WFD to set up monitoring programmes to provide sufficient data for reliably assessing the status of the relevant quality element. The measurement frequencies depend on the water category (e.g. streams and rivers, lakes), the biological quality element (e.g. phytoplankton, macroinvertebrates, fish), and on the ecological status of the water body under consideration. Consequently, the selection of quality elements and the frequency of monitoring vary greatly between the EU member states (Hering et al., 2010; Pasztaleniec, 2016). The WFD differentiates between surveillance monitoring, operational monitoring and investigative monitoring. Surveillance monitoring is performed for all biological, hydromorphological and physical and chemical quality elements, and investigative monitoring is carried out if the status of the water body is lower than good. Operational monitoring is used for assessing the status of those water bodies at risk of failing to meet their environmental objectives, and it is the most widespread monitoring tool. For operational monitoring, the minimum requirement for phytoplankton listed in Annex V of the WFD is twice per year, but most member states apply higher sampling frequencies. For large (>50 ha) Austrian lakes, the assessment of phytoplankton is based on the annual mean of data acquired from at least four sampling dates per year (Wolfram et al., 2013). Seasonal sampling shall capture the spring circulation, the beginning and peak of the summer stagnation, and the beginning of the autumn circulation. If a water body does not reach a high or good ecological status, member states are asked to perform mitigation actions listed in the WFD, Article 11(5) (e.g. investigation of causes of the possible failure, reviewing monitoring programmes or additional measures).

The adequate phytoplankton sampling frequency in lakes is a much-debated issue (Dixon \& Chiswell, 1996; Carstensen, 2007; Carvalho et al., 2007; Domingues et al., 2008; Hering et al., 2010). Wolfram et al. (2013) noted that a higher sampling frequency than four times per year will improve the confidence in the calculation and avoid biases of the annual means due to outliers. Carvalho et al. (2007) recommended monthly sampling for both chlorophyll and phytoplankton composition. Carstensen (2007) concluded that the required monitoring efforts to ensure a precise quality assessment are substantially higher than envisaged in the WFD and, for phytoplankton and nutrients, may be as high as 500 observations to characterise a water body. However, a trade-off exists between the improved precision obtained by sampling more frequently and the economics of monitoring (Skeffington et al., 2015).

This issue has gained renewed momentum in recent years because, despite all preservation acts (e.g. decreasing the nutrient input by improving wastewater treatment and banning phosphates from detergents) water bodies are increasingly susceptible to eutrophication in the course of climate change. Climate research predicts rising air temperatures and an increased frequency and intensity of environmental disturbances such as heat waves and heavy rain events in central Europe and other temperate regions (Beniston et al., 2007; IPCC, 2013). In Austria, the frequency of meteorological droughts has increased since 1950 (European Environment Agency, 2017), and an increase in summer surface water temperature of at least $2^{\circ} \mathrm{C}$ by 2050 has been predicted for 15 Austrian lakes (Dokulil, 2014). Austria is also projected to experience the highest increase in flood risk among European countries (Alfieri et al., 2015). Consequently, lakes are at risk of climate-induced eutrophication (Moss, 2008), as rising air temperature 
increases the external and internal nutrient loading by accelerating the rate of mineralisation in catchment soils and in lakes (Malmaeus et al., 2006). Higher evapotranspiration may further increase the phosphorus concentration in lakes (Jeppesen et al., 2005). Taken together, these expectations lead to an often undesirable higher algal biomass and a shift to cyanobacterial dominance in lakes (Moss, 2008; Rigosi et al., 2014). The WFD monitoring programmes should keep track of this warming-induced eutrophication.

Extreme meteorological events can have various effects on phytoplankton communities. For example, in the course of a heat wave the risk of algal blooms increases as incoming nutrients are retained for longer periods and fewer algae are flushed from the system. In particular, cyanobacteria are favoured by heat wave conditions (Jöhnk et al., 2008). Contrary to heat waves, which are characterised by increases in water column stability, heavy rain events increase flushing rates and therefore nutrient loads into the lake, stimulating phytoplankton growth, but heavy rain may also reduce phytoplankton biomass due to removal or dilution (Znachor et al., 2008).

The quest for cost-effectiveness and increased precision has stimulated the search for computeraided, automated high frequency monitoring. Such analytical tools (sensors) are available for physical and chemical water quality elements (e.g. temperature and nutrients; (Chavez et al., 1997; Tokar \& Dickey, 2000; Blain et al., 2004; Skeffington et al., 2015)). Continuous lake observatories, which are often linked to the Global Lake Ecological Observatory Network (GLEON), have been implemented in the Americas, Europe, Australia, and New Zealand (Hamilton, 2014; Rose et al., 2016, and references therein).

Automatic sampling and analysis are more difficult for biological water quality elements, although progress has been made in the field of automated and traitbased analyses of natural phytoplankton communities (Pomati et al., 2011). Within the EU water monitoring programmes, analysis of nano- and microphytoplankton abundance is still routinely done by inverted light microscopy (Utermöhl, 1958). However, despite the obvious success of a method being in use for more than half a century, the Utermöhl technique has several disadvantages. In particular, this technique is time consuming, allowing the processing of only a small number of samples per day; secondly, it is subjective, i.e. depending on the taxonomic skills of the observer; and, thirdly, potentially biased because cells have to be chemically fixed prior to counting and chemical fixation might cause cell shrinkage or lysis (Hobro \& Willén, 1977; Rott, 1981; Montagnes et al., 1994; Culverhouse et al., 2003; Vuorio et al., 2007; Straile et al., 2013). Furthermore, picocyanobacteria, which contribute significantly to total phytoplankton biomass in many lakes (Weisse, 1993; Callieri \& Stockner, 2002; Stomp et al., 2007), are too small to be detected by inverted microscopy and are, therefore, excluded from the routine analysis.

Numerous attempts have been made to replace the traditional Utermöhl technique by (semi-) automated analytical devices, which were primarily developed for marine environments to reduce sampling processing time and to objectivise the analyses. These devices comprise various (in situ) imaging systems such as imaging flow cytometers with their respective software (reviewed by Benfield et al., 2007). In recent years, novel molecular tools have replaced classical DNA Sanger sequencing in aquatic microbiology; quantitative PCR, high throughput sequencing, metatranscriptome and proteome analyses are increasingly being used to characterise taxonomic and functional diversity of (marine) microorganisms including phytoplankton (reviewed by Johnson \& Martiny, 2015). However, quantification of the entire phytoplankton species composition and biomass is still difficult with the molecular protocols currently available (Johnson \& Martiny, 2015; Xiao et al., 2014), and the application of the molecular tools by monitoring agencies has been limited (e.g. Wollschläger et al., 2014; Wood et al., 2013).

Our study pursued two major goals; first, using the standard Utermöhl (1958) technique, we assessed the effect of increased sampling frequency (monthly vs seasonal) on the calculation of the annual mean phytoplankton biomass and EQR assessments. In particular, we postulated that sampling during extreme events, which are often missed in low-frequency routine monitoring programmes, reduces the calculated annual biovolume of taxa that are sensitive to disturbances and increases the biomass of other, more robust taxa that may take advantage of increased temperature and/or reduced competition in the course of disturbances. Several experimental microcosm and mesocosm studies have already demonstrated these mechanisms for dominant freshwater phytoplankton 
taxa (Rasconi et al., 2015, 2017; Weisse et al., 2016). Secondly, we hypothesised that the methodology of the current monitoring programmes underestimates various phytoplankton groups, namely small and fragile cells or colonies that are sensitive to fixation and/or difficult to detect with the common resolution of light microscopy (Gieskes \& Kraay, 1983; Rodriguez et al., 2002). To this end, we analysed the quantity and identity of the phytoplankton communities using a novel combination of imaging flow cytometry, acoustic flow cytometry and conventional light microscopy combined with image analysis. We used prealpine Lake Mondsee (Austria) for this case study. We analysed data published within the Austrian WFD reports together with unpublished data to test the above hypotheses. The present work is a follow-up of a previous study that investigated in detail the phytoplankton response in Lake Mondsee to the 2015 summer heat wave (Bergkemper \& Weisse, 2017).

\section{Materials and methods}

Study site

Lake Mondsee is a prealpine, oligo-mesotrophic, deep stratified lake located in central Austria $\left(47^{\circ} 50^{\prime} \mathrm{N}\right.$, $\left.13^{\circ} 23^{\prime} \mathrm{E}\right)$. The lake has mean and maximum depths of 34 and $68 \mathrm{~m}$, respectively, and a surface area of $13.78 \mathrm{~km}^{2}$. The lake regularly stratifies during summer; however, ice-coverage in winter is sporadic and rarely complete. The last complete freeze-over occurred in 1963 (Einsele, 1963). Lake Mondsee is an example of an originally ice-covered temperate lake undergoing a transition from a dimictic to a monomictic mixing pattern in the course of the ongoing lake warming (Ficker et al., 2017). Lake Mondsee is one of the best studied lakes in Austria with long-term phytoplankton datasets from the last 40 years (Findenegg, 1969; Dokulil \& Skolaut, 1986; Dokulil \& Jagsch, 1992; Greisberger et al., 2008; Dokulil \& Teubner, 2012). Even longer records ( $>50$ years) are available for some abiotic parameters such as Secchi depth (Dokulil et al., 2000). Since 2007, Lake Mondsee has been monitored according to the WFD, originally with four samplings per year during (1) spring circulation, (2) start of summer stagnation, (3) peak of summer stagnation, and (4) start of autumn circulation. As Lake Mondsee did not reach the "good ecological status" required by the WFD in 2008, this seasonal sampling was replaced by a monthly sampling in 2009. By 2012, Lake Mondsee had reached the "good ecological status" (Schafferer \& Pfister, 2016).

The annual phytoplankton biomass in the upper $20 \mathrm{~m}$ of L. Mondsee is dominated by diatoms and filamentous cyanobacteria (mainly Planktothrix rubescens (De Candolle ex Gomont) Anagnostidis \& Komárek). This deep-living cyanobacterium is also an important indicator species for ecological status assessments. Higher $P$. rubescens abundances may lead to downgrading of the ecological status in (meso-) oligotrophic lakes (Wolfram et al., 2015). Cryptophytes and chrysophytes are also abundant in L. Mondsee (Dokulil \& Teubner, 2012). Single-celled phycoerythrin-rich picocyanobacteria occur in high numbers $\left(>10^{5}\right.$ cells $\mathrm{ml}^{-1}$ ) in the epilimnion during summer (Crosbie et al., 2003; T. Weisse, Research Department for Limnology, Mondsee, unpubl. data).

\section{Sampling}

Lake Mondsee was sampled monthly during 2009 to 2015. Samples were taken by the Institute for Freshwater Ecology, Fisheries Biology and Lake Research of the Federal Agency for Water Management, Scharfling, Austria, at the beginning of each month. All samples were taken at the deepest site of Lake Mondsee and were integrated from 0 to $21 \mathrm{~m}$. Further information of the sampling methodology can be gathered from the following website: http://wisa. bmlfuw.gv.at/fachinformation/ngp/ngp-2015.html.

The WFD phytoplankton assessments of Lake Mondsee are published at http://www.landoberoesterreich.gv.at/12991.htm.

In 2015 and 2016, we took integrated samples (0-21 m) midmonth at the same site, alternating with the samplings conducted by the Federal Agency for Water Management. To minimise errors arising from different sampling procedures, we applied the same sampling methodology as our colleagues from Scharfling. Additional samples (one sample per sampling station, Fig. 1) were taken during two heavy rain events on 30 March 2015 and 02 February 2016 and during a heat wave in 2015 (30 June, 02 July, 06 July and 09 July 2015). We defined a heavy rain event in the Mondsee catchment area as rainfall $>50 \mathrm{~mm}$ within $24 \mathrm{~h}$. Water temperatures were assessed using a 
Fig. 1 Soluble reactive phosphorus (SRP) concentrations at various sampling stations across Lake Mondsee (black circles) and its main tributaries (open circles) during two heavy rain events in 2015 and 2016. The star marks the central station (S3) of the lake, which is also the deepest site of the lake. FA Fuschler Ache, $W K$ Werkskanal, ZA Zeller Ache and WA Wangauer Ache

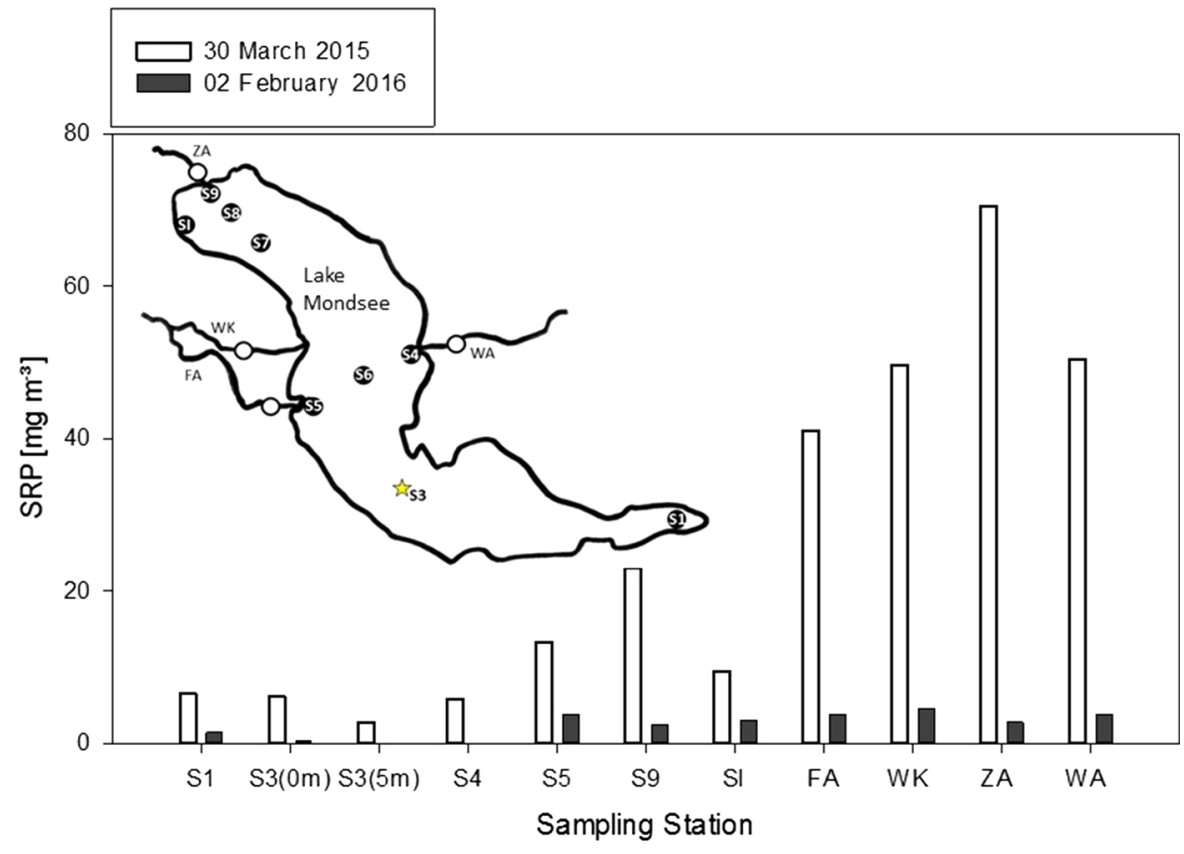

multiparameter probe (YSI 6600 V2, Yellow Springs Instruments, USA). Soluble reactive phosphorus (SRP) was analysed spectrophotometrically after $0.2 \mu \mathrm{m}$ filtration using standard operating procedures (Vogler, 1966). During the extreme events SRP concentrations were analysed on each sampling day from 7 to 9 sampling stations within the lake [surface samples or integrated samples (0-21 m)], and from samples taken from distinct depths $(0,5 \mathrm{~m})$ at the central station of the lake. Additionally, 4 surface samples from the main tributaries of Lake Mondsee (i.e. Fuschler Ache, Werkskanal, Zeller Ache and Wangauer Ache) were analysed in regard to SRP concentrations (Fig. 1). Phytoplankton was analysed biweekly from Lugol's fixed material using light microscopy and from live samples by FlowCAM and flow cytometry.

Comparison of monthly versus seasonal sampling

We assessed differences in mean phytoplankton biovolumes using the data from the monthly WFD sampling compared to an 'artificial' seasonal dataset. Data were abstracted from seven annual WFD reports covering the period from 2009 to 2015 (Mildner et al., 2011, 2012, 2013; Schafferer \& Pfister; 2014, 2015, 2016; Wolfram et al., 2010). The reports also list sampling procedures, number of cells counted for each taxon, etc. Change in personnel occured only once during the study period (from 2012-2013). The seasonal dataset was derived from the original WFD dataset by only considering samples from the (1) spring circulation (March or April sampling), (2) start of summer stagnation (June sampling), (3) peak of summer stagnation (August sampling), and (4) start of autumn circulation (November sampling). The seasonal dataset was extracted from the monthly dataset, i.e. the latter included the data of the former plus eight additional monthly samples. To estimate the annual biovolume of each taxon, average biovolumes from monthly $\left(N=12\right.$ samples year $\left.{ }^{-1}\right)$ and seasonal $\left(N=4\right.$ samples year $\left.{ }^{-1}\right)$ sampling frequencies were compared. Heterotrophic taxa were excluded from EQR calculations, according to the standard protocol (Wolfram et al., 2015). The Brettum index (BI), EQR and nEQR were calculated after Wolfram et al. (2015 and references therein) for 2009-2015. The overall $\mathrm{EQR}$ is the arithmetic average of the $\mathrm{nEQR}$ values for chlorophyll a (Chl-a) concentration, biovolume and the BI. Chlorophyll a concentrations were only available for the years 2013-2015. Therefore, the overall annual EQR for the years 2009-2012 was calculated using the average of the $\mathrm{nEQR}$ values for biovolume and BI. Finally, three-year running averages of the value 'nEQR overall' (Table 1) were 
Table 1 Comparison of normalised ecological quality ratio (nEQR) values using the monthly versus the seasonal $(N=4$ samples year $^{-1}$ ) sampling strategy

\begin{tabular}{|c|c|c|c|c|c|c|c|c|c|c|c|c|}
\hline \multirow{3}{*}{ Year } & \multicolumn{6}{|c|}{ Monthly sampling } & \multicolumn{6}{|c|}{ Seasonal sampling } \\
\hline & \multirow{2}{*}{$\begin{array}{c}\text { Annual } \\
\text { average } \\
\text { biovolume } \\
{\left[\mathrm{mm}^{3} \mathrm{~L}-1\right]}\end{array}$} & \multicolumn{5}{|c|}{ nEQR } & \multirow{2}{*}{$\begin{array}{c}\text { Annual } \\
\text { average } \\
\text { biovolume } \\
{\left[\mathbf{m m}^{3} \mathbf{L}-1\right]}\end{array}$} & \multicolumn{5}{|c|}{ nEQR } \\
\hline & & Chl-a & $\begin{array}{c}\text { Bio- } \\
\text { volume }\end{array}$ & BI & $\begin{array}{l}\text { nEQR } \\
\text { overall }\end{array}$ & $\begin{array}{c}\text { 3-Year } \\
\text { average }\end{array}$ & & Chl-a & $\begin{array}{c}\text { Bio- } \\
\text { volume }\end{array}$ & BI & $\begin{array}{l}\text { nEQR } \\
\text { overall }\end{array}$ & $\begin{array}{l}\text { 3-Year } \\
\text { average }\end{array}$ \\
\hline 2015 & 0.62 & 0.68 & 0.69 & 0.71 & 0.7 & 0.74 & 0.77 & 0.66 & 0.65 & 0.7 & 0.68 & 0.72 \\
\hline 2014 & 0.32 & 0.82 & 0.91 & 0.79 & 0.83 & 0.72 & 0.39 & 0.81 & 0.82 & 0.8 & 0.81 & 0.69 \\
\hline 2013 & 0.68 & 0.61 & 0.67 & 0.75 & 0.7 & 0.64 & 0.99 & 0.55 & 0.6 & 0.74 & 0.66 & 0.61 \\
\hline 2012 & 0.79 & n.a. & 0.64 & 0.65 & 0.64 & 0.61 & 0.87 & n.a. & 0.62 & 0.59 & 0.61 & 0.58 \\
\hline 2011 & 1.21 & n.a. & 0.54 & 0.64 & 0.59 & 0.63 & 1.47 & n.a. & 0.49 & 0.62 & 0.56 & 0.6 \\
\hline 2010 & 1.36 & n.a. & 0.51 & 0.67 & 0.59 & n.a. & 1.68 & n.a. & 0.47 & 0.65 & 0.56 & n.a. \\
\hline 2009 & 0.98 & n.a. & 0.6 & 0.83 & 0.72 & n.a. & 1.15 & n.a. & 0.56 & 0.82 & 0.69 & n.a. \\
\hline
\end{tabular}

The boundary value between moderate and good ecological status is 0.6 , and the boundary value between good and high ecological status is 0.8. Normalised EQR values for chlorophyll a (Chl-a) could only be calculated for the years 2013-2015 as no Chl-a data were available before 2013. Biovolume and Chl-a data are available from the published annual WFD reports from Lake Mondsee. The Brettum Index (BI) nEQR and the overall nEQR (using the combined nEQR from Chl-a, biovolume and BI-Index) were calculated after (Wolfram et al., 2015). The 3-year average of the ecological status was calculated for both sampling strategies. The ecological status of the various parameters is visualised by colouring the cells. Yellow moderate, Green good, Blue high

calculated, as this is the final evaluation method for the ecological status assessments of Austrian lakes.

Instruments used for phytoplankton counting and biovolume assessments

Samples for microscopic analyses were fixed with acidic Lugol's solution ( $0.2 \%$ final concentration) immediately after sampling and stored in amber glass bottles in the dark until analysis. Monthly biovolume estimates using light microscopy were conducted by the KIS Kärntner Institut für Seenforschung GMbH, Klagenfurt, Austria (2009-2012), and ARGE Limnologie, angewandte Gewässerökologie GesmbH, Innsbruck, Austria (2013-2015). Samples taken in the midst of each month and from extreme events in 2015 were analysed in our laboratory, using a compound plate chamber (Hydro-Bios No. 435,025). All phytoplankton cell counts and biovolume estimations conducted by KIS, ARGE and in our laboratory were conducted according to the Standard Operating Procedure for Phytoplankton Analyses [revised 2010 (LG401) https://www.yumpu.com/en/document/view/ 13413293/standard-operating-procedure-for-phyto plankton-analysis-]. The Standard operating procedure requires a sample volume of $10-50 \mathrm{ml}$ (depending on cell density), and the minimum count is 250 organisms. We standardised $P$. rubescens counting and biovolume estimations according to ARGE.

The FlowCAM (flow cytometer and microscope, Fluid Imaging technology, Yarmouth, ME, USA), is a combination of a flow cytometer and a microscope with a digital camera attached. It characterises each particle within a sample with $>30$ morphological and fluorescence parameters (Sieracki et al., 1998). Live subsamples of the integrated samples, which were also used for light microscopy after fixation, were analysed within $6 \mathrm{~h}$ after sampling. The sample was filtered through a $200 \mu \mathrm{m}$ mesh gauze to prevent clogging of the $80 \mu \mathrm{m}$-wide FC-80FV flow cell and analysed using the $\times 10$ objective analysing $1 \mathrm{ml}$ sample volume at a flow rate of $0.15 \mathrm{ml} \mathrm{min}{ }^{-1}$. For our analyses, we only used the $\times 10$ objective as it allows capturing a wide size range $(4-200 \mu \mathrm{m})$. Flow cytometric assessment was used for the smaller taxa and the larger, less abundant taxa were counted using light microscopy. The relatively long time (approximately $1 \mathrm{~h}$ ) needed to change FlowCAM objectives and flow cells and to adjust the instrument settings discouraged us from changing the equipment during the measurements. Live analyses of FlowCAM and flow cytometry were performed in parallel to each other within 
3-4 h after sampling, later followed by microscopic analyses of fixed samples (microscopic analyses were conducted within 4 months after sampling). This combination of methods allowed to capture the entire phytoplankton size spectrum. FlowCAM measurements were conducted in trigger mode using the green laser installed $(532 \mathrm{~nm})$ to excite cellular Chl-a and accessory pigments such as phycoerythrin. Images were analysed using the Visual Spreadsheet software (Version 3.7.5). To capture all algal cells within the sample, we used FlowCAM settings with which particles were captured and defined by dark and light pixels (Visual Spreadsheet Menu $\rightarrow$ Context $\rightarrow$ Capture $\rightarrow$ Particles defined by...). Therefore, both relatively dark algae such as cryptophytes and dinoflagellates but also relatively transparent algae (e.g. diatoms and chrysophytes) were captured in the same run. However, using these settings also leads to possible miscalculations of the physical dimensions of the captured particles ('halo effect', i.e. for dark particles with bright halos and for bright particles with dark halos the actual particle size may be overestimated). To quantify the possible bias resulting from the halo effect, we used dark and light pixels in the first run and dark pixels only in the second run of four selected samples each. Based upon these measurements, we calculated correction factors ( $\mathrm{CFs}$ ) for several taxonomical groups by relating the morphological measurements taken with the "dark only" settings to those obtained with the "dark and light" settings. These correction factors were then applied for biovolume calculations of particles captured using the "dark and light" settings. Cell or colony biovolumes were calculated using either (1) the volume calculation (ABD) provided by FlowCAM (with correction factors where applicable), or (2) according to taxonspecific cell volume formulas defined by the Standard Operating Procedure for Phytoplankton Analyses, using FlowCAM length and width measurements (with correction factors where applicable), or (3) using cell biovolumes derived from microscopic analyses of the same year, or (4) from the literature. The exact method for the biovolume estimation for each operational taxonomic group captured with the FlowCAM is shown in Supplementary Table 1.

Live subsamples from all samples taken in 2015 and 2016 were also analysed using flow cytometry. We used an Attune ${ }^{\circledR}$ NxT Acoustic Focusing Cytometer (Life Technologies, Thermo Fisher Scientific Inc) equipped with violet ( $405 \mathrm{~nm}, 50 \mathrm{~mW})$, blue (488 nm, $50 \mathrm{~mW}$ ) and yellow (561 nm, $50 \mathrm{~mW}$ ) lasers to count live phytoplankton samples, in particular picocyanobacteria. This acoustic flow cytometer uses ultrasonic waves ( $>2 \mathrm{MHz}$ ), rather than hydrodynamic forces applied in conventional flow cytometry, to align cells into a single, focused line along the central axis of the measuring capillary. The measuring principle has been recently described (Bergkemper \& Weisse, 2017). With the auto sampler connected to the Attune flow cytometer, up to 96 samples can be measured automatically. With the software FlowJo that we used in the present study or similar software programmes, flow cytometric data can be analysed rapidly and largely automatically, once the 'gates' (i.e. regions placed around populations of cells with common characteristics) for the target populations under study have been defined. Instrument settings were optimised using the Attune Cytometric Software. Forward scatter (FSC) and BL3 autofluorescence $(595 / 40 \mathrm{~nm})$ were used as triggers with low thresholds for all measurements. A sample volume of $0.5 \mathrm{ml}$ was analysed at a flow rate of $0.1 \mathrm{ml} \mathrm{min}{ }^{-1}$. Analyses of the data files (fcs format) were conducted with the software programme FlowJo v10.1 (FLOWJO, LLC). Picocyanobacterial biomass was calculated from flow cytometric cell numbers assuming an average particle volume of $1 \mu \mathrm{m}^{3}$ (see "Discussion").

\section{Statistical analyses}

Statistical analyses were conducted using the software R (R Development Core Team, 2011) and SigmaPlot 12.5 from Systat Software, Inc., San Jose California USA, www.systatsoftware.com. Figures were created using SigmaPlot. We tested for differences in mean annual phytoplankton biovolumes calculated from monthly sampling and seasonal sampling for the years 2009-2015. All datasets (i.e. mean annual biovolumes derived from monthly and seasonal samplings and corresponding nEQR values, and overall $\mathrm{nEQR}$ values) were tested for deviation from normal distribution (Shapiro-Wilk normality test). As all data but 3-year averages $\mathrm{nEQR}$ values were normally distributed, using paired student's $t$ tests to test for statistical differences in average annual phytoplankton biovolume and nEQR values of the two different sampling strategies seems appropriate. However, due to the small sample size $(n=7)$, normality tests such as the 
Shapiro-Wilk normality test have limited power to reject the null hypothesis (i.e. $H_{0}=$ normal distribution of data). Therefore, we calculated the non-parametric Wilcoxon signed-rank test as an alternative to the paired student's $t$ test and report results of the former in the following. Qualitatively, paired $t$ test and Wilcoxon signed-rank test yielded the same results in each case. Furthermore, annual biovolume estimates versus annual variability were compared for the years 2009 to 2015 using linear regression analyses to test whether higher variability also leads to higher averages in phytoplankton biovolume. The increase of chlorophyte biovolume during the heat wave 2015 was tested for significance using the $1 \mathrm{~m}$ function implemented in $\mathrm{R}$ for linear regression analysis.

\section{Results}

Effect of sampling frequency on phytoplankton biovolume estimations and lake status assessments

Annual phytoplankton biovolumes calculated from monthly sampling differed significantly (Wilcoxon signed-rank test, $P=0.016$ ) from biovolumes estimated from seasonal sampling during 2009-2015 (Table 1). The overall annual mean phytoplankton biovolumes $( \pm \mathrm{SD})$ calculated for the period 2009-2015 was $0.85 \pm 0.33 \mathrm{~mm}^{3} \mathrm{l}^{-1}$ based on monthly sampling and $1.05 \pm 0.40 \mathrm{~mm}^{3} \mathrm{l}^{-1}$ for the seasonal sampling. The annual spring peak was captured by both sampling frequencies (Fig. 2). High phytoplankton biovolumes in spring were recorded during 2009, 2010, 2011 and 2013. Higher annual variance resulting from overproportionally high spring biovolumes (relative to the rest of the year) were correlated to mean annual phytoplankton biovolumes (linear regression analyses, $R^{2}=0.83, P<0.001$ ). Brettum Index $\mathrm{nEQR}$ values were significantly lower by the seasonal sampling frequency compared to using the monthly sampling frequency (Wilcoxon signedrank test, $P=0.047$ ). Overall $\mathrm{nEQR}$ values derived from seasonal sampling were significantly lower than the ones derived from monthly sampling (Wilcoxon signed-rank test, $P=0.016$ ). The 3 -year $\mathrm{nEQR}$ averages were also lower in seasonal samplings compared to monthly samplings, but the difference was not significant (Wilcoxon signed-rank test, $P=0.063$ ). The overall nEQR value derived from seasonal sampling resulted in downgrading of the ecological status ( $\mathrm{nEQR}=0.58$, i.e. moderate) of Lake Mondsee for the three-year average 2010-2012, compared to the estimate calculated from monthly sampling $(\mathrm{nEQR}=0.61$, i.e. good) (Table 1).

Climate data and phosphorus load to Lake Mondsee during episodes of heavy rain in 2015 and 2016

The year 2015 was the second warmest year ever recorded in Austria. Similar to the countrywide average, the average annual air temperature at Mondsee $\left(10.0^{\circ} \mathrm{C}\right)$ was $1.5^{\circ} \mathrm{C}$ higher in 2015 than the longterm (1981-2010) average (Zentralanstalt für Meteorologie und Geodynamik, ZAMG; http://www.zamg. ac.at/cms/en/climate/climate-overview/current_ climate). Annual precipitation in Austria was below average in 2015 (at Mondsee, $1425 \mathrm{~mm} \mathrm{year}^{-1}$, i.e. $91 \%$ of the long-term average). However, a heavy rain event $\left(\sim 50 \mathrm{~mm}\right.$ precipitation day $^{-1}$ ) was recorded

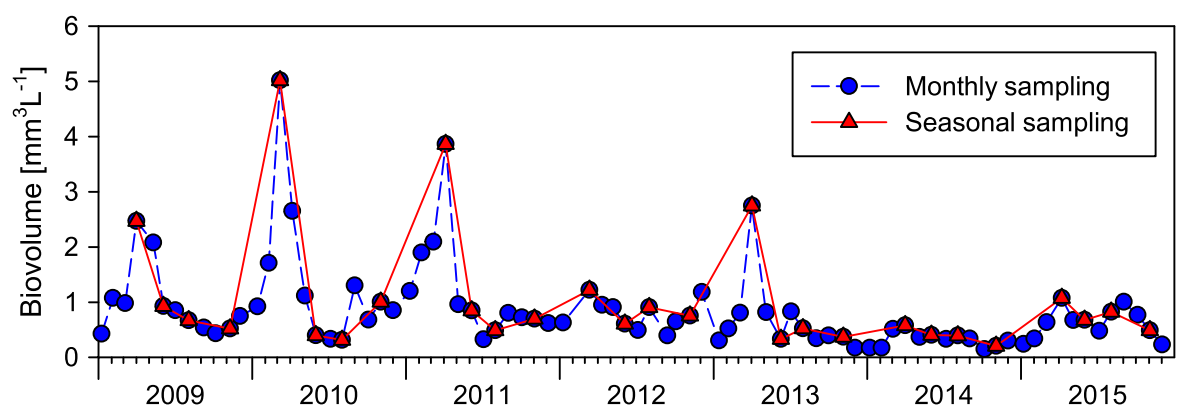

Fig. 2 Phytoplankton biovolume (0-21 m average) at the central sampling station of Lake Mondsee (2009-2015) assessed from monthly and seasonal samples 
on 29/30 March 2015 in the catchment area of Lake Mondsee; this episode coincided with the peak of the snowmelt. In summer of 2015, several heat waves consisting of at least three consecutive days with maximum air temperature $\geq 30.0^{\circ} \mathrm{C}$ ('tropical days' in the terminology of meteorologists) occurred. In July-August, 2015, a record 28 tropical days were recorded at Mondsee (ZAMG, 2017; Bergkemper \& Weisse, 2017). In the following year, 2016, the average annual air temperature at Mondsee $\left(9.7^{\circ} \mathrm{C}\right)$ was less extreme, and only 8 tropical days were recorded during the whole year (ZAMG, 2017). Annual precipitation in Mondsee 2016 was $1730 \mathrm{~mm}$ and therefore $17.6 \%$ higher than in 2015. A heavy rain event was recorded on 01/02 February 2016 ( $70 \mathrm{~mm}$ precipitation days $^{-1}$ ), several weeks before the peak of the snow melt.

SRP concentrations measured twice per month in 2015 and 2016 were under the detection limit during summer stagnation and ranged from 1 to $9 \mu \mathrm{g} 1^{-1}$ during spring circulation at the central station (0-21 m) during routine monitoring. The measured SRP concentrations in the main tributaries as well as within Lake Mondsee were higher by approximately one order of magnitude during the heavy rain event in 2015 compared to the heavy rain event in 2016 (Fig. 1). Within the Fuschler Ache (sampling station FA), the SRP concentration was $41 \mu \mathrm{g}^{-1}$ on 30 March 2015 and $3.8 \mu \mathrm{g} \mathrm{1^{-1 }}$ on 02 February 2016.

Changes of phytoplankton biovolume during extreme events

We calculated a total phytoplankton biovolume of $0.32 \mathrm{~mm}^{3} \mathrm{l}^{-1}$ during the heavy rain event on 30 March 2015 and only $0.04 \mathrm{~mm}^{3} 1^{-1}$ during the heavy rain event on 02 February 2016 using FlowCAM (Fig. 3). The majority of the phytoplankton classes did not show an immediate response to the heavy rain events (Fig. 4). However, with FlowCAM, we observed a drastic decline in cryptophyte biomass at the end of March 2015 and beginning of February 2016, followed by rapid recovery of the populations (Fig. 4f). These ups and downs were not obvious from the monthly samples using the Utermöhl technique with fixed material (Fig. 4f). The average annual biomass of cryptophytes was $0.075 \pm 0.025 \mathrm{~mm}^{3} 1^{-1}$ in 2015 and $0.071 \pm 0.030 \mathrm{~mm}^{3} 1^{-1}$ in 2016 calculated from FlowCAM samples. When the samplings of the heavy rain events were excluded, the average annual cryptophyte biovolume amounted to $0.077 \pm 0.023 \mathrm{~mm}^{3}$ $1^{-1}$ in 2015 and $0.074 \pm 0.027 \mathrm{~mm}^{3} \mathrm{l}^{-1}$ in 2016, i.e. the average annual cryptophyte biomass would have been higher by $2 \%$ (in 2015), respectively $4 \%$ (in 2016) if the periods of heavy precipitation were ignored. For all other phytoplankton taxa, the biomass was either too low to detect any significant changes or appeared unaffected by the heavy rain events (Fig. 4).

During the first heat wave at the end of June/ beginning of July 2015, P. rubescens biovolume integrated over the upper $21 \mathrm{~m}$ of the water column generally increased, but also strongly declined on the third day (6 June 2015) of the heat wave (Fig. 5). The microscopic analyses from the WFD monitoring did not capture these short-term changes of $P$. rubescens biovolumes. Including results from the four samples taken during the heat wave, the average annual biovolume of $P$. rubescens was $0.226 \pm 0.151 \mathrm{~mm}^{3}$ $1^{-1}$ in 2015 , compared to $0.153 \pm 0.091 \mathrm{~mm}^{3} \mathrm{l}^{-1}$ if the heat wave samples were not considered; i.e. the average annual biovolume was $32 \%$ higher when the heat wave dataset was included.

According to our FlowCAM analyses, chlorophyte biovolumes increased significantly from 0.002 to $0.036 \mathrm{~mm}^{3} 1^{-1}$ in the course of the heat wave (linear regression analyses, $R^{2}=0.98, \mathrm{n}=4, P<0.01$, Fig. 4c). The average annual biovolume of chlorophytes was $0.0123 \pm 0.011 \mathrm{~mm}^{3} \mathrm{l}^{-1}$ in 2015 considering the heat wave samples and $0.0109 \pm 0.009 \mathrm{~mm}^{3}$ $1^{-1}$ when the heat wave samples were excluded, i.e. the additional sampling during the heat wave increased the calculated average annual biovolume by $11.4 \%$. Chlorophytes were mainly composed of Oocystis sp. colonies and small single-celled species such as Chlorella sp. The chlorophyte biovolume calculated from FlowCAM did not only increase during the first heat wave but remained high throughout summer, 2015, with a short decline at the beginning of August; this decline, which coincided with a short-term drop of water temperature (Fig. 3), was not evident from the routine light microscopic cell counts (Fig. 4c).

Phytoplankton abundance and biovolume estimated by light microscopy, FlowCAM and flow cytometry

The overall phytoplankton biovolume derived from FlowCAM measurements during 2015 and 2016 was 
Fig. 3 Total phytoplankton biovolume derived from FlowCAM measurements, monthly average air temperatures and surface water temperatures during 2015 and 2016. Samples taken during extreme events are marked by blue bars (heavy rain events) and a red bar (heat wave)

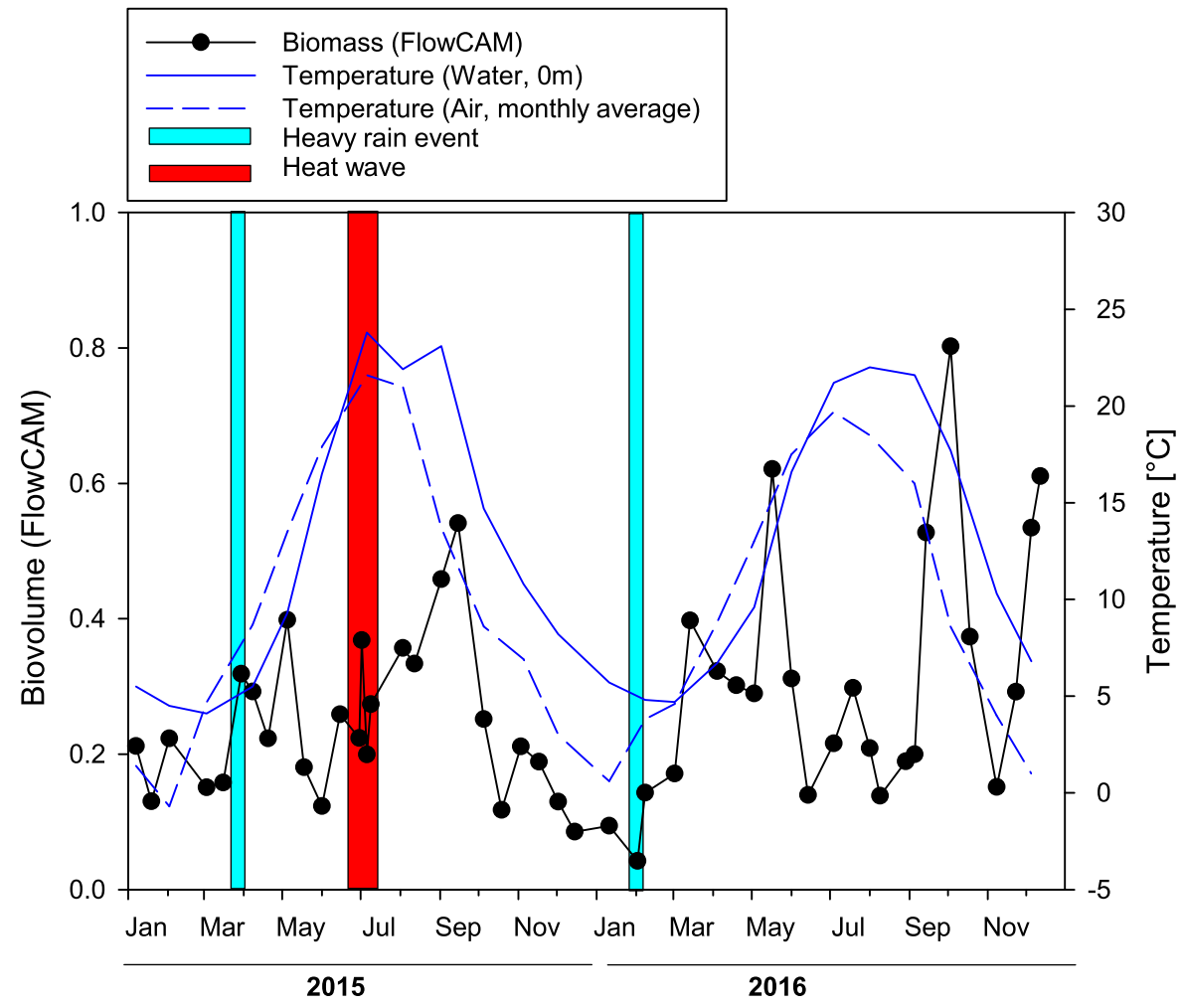

Because of a change in the instrument configuration in March 2015, we report flow cytometric picocyanobacterial cell numbers from spring 2015 until the end of 2016 and compare the average values recorded during the summer stratification period from April through October of these years (Fig. 6). During this period, the average picocyanobacterial cell number $(0-21 \mathrm{~m})$ was twice as high in $2015\left(1.23 \times 10^{5}\right.$ $\left.\mathrm{ml}^{-1}\right)$ than in $2016\left(0.56 \times 10^{5} \mathrm{ml}^{-1}\right)$. These cell numbers are somewhat underestimated, because an unequivocal discrimination between single-celled picocyanobacteria, doublets and small microcolonies was not possible with the Attune flow cytometer (see Discussion, below). Therefore, in a strict sense, the numbers reported in Fig. 6 refer to particle numbers. Assuming an average biovolume of $1 \mu \mathrm{m}^{3}$ particle $^{-1}$, the average summer 'cell' numbers convert to average picocyanobacterial biovolumes of $0.12 \mathrm{~mm}^{3} \mathrm{l}^{-1}$ in 2015, and $0.06 \mathrm{~mm}^{3} \mathrm{1}^{-1}$ in 2016. Although we cannot rule out that an early spring peak, similar to 2016 (Fig. 6), occurred in 2015, we assume that the abundance was lower during the first three months of 2015 , similar to the values recorded at the end of 2015 . 

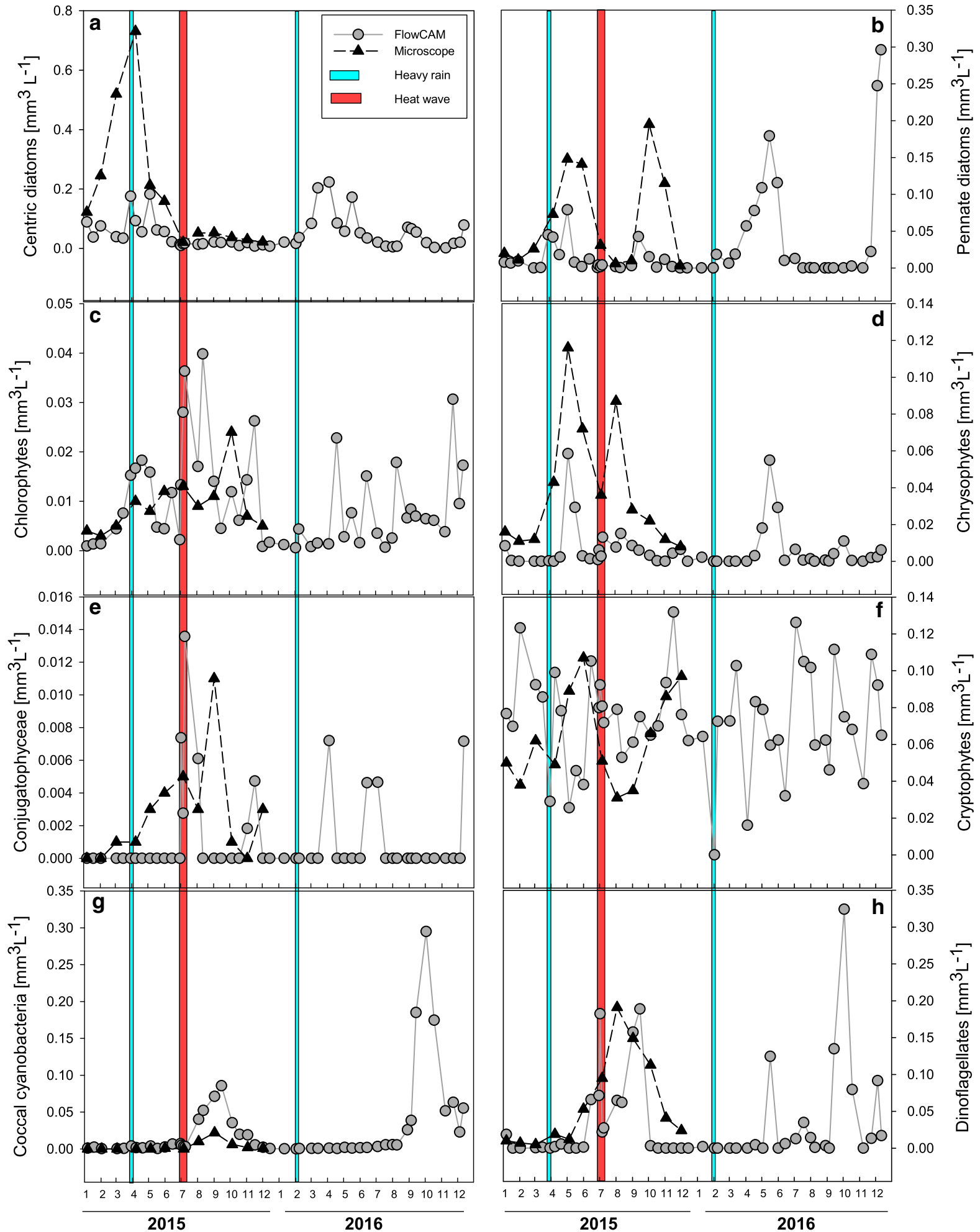

Fig. 4 Phytoplankton biovolumes estimated by FlowCAM during 2015 and 2016 and inverted light microscopy (2015 only). Samples taken during extreme events are marked by blue bars (heavy rain events), respectively a red bar (heat wave) 
Fig. 5 Planktothrix rubescens biovolume in Lake Mondsee during 2015. Integrated samples $(0-21 \mathrm{~m})$ were taken at the deepest site of Lake Mondsee. The red bar highlights the samples taken during the heat wave. The solid blue line denotes surface water temperature

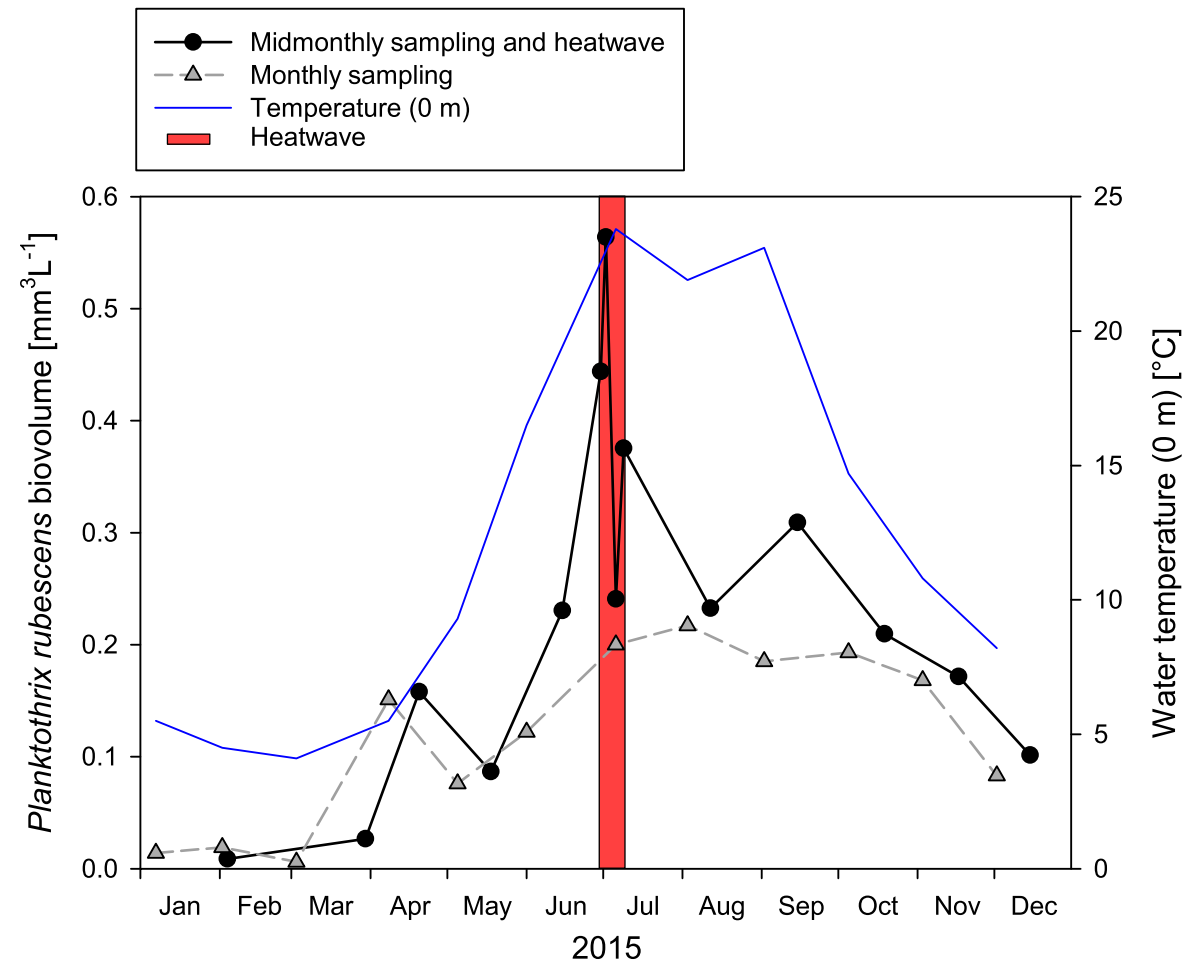

Discussion

Effect of sampling frequency on average annual phytoplankton biovolume and ecological status assessment

Effective monitoring of lakes requires choosing an appropriate sampling strategy, balancing the trade-off between improved precision by increased sampling frequencies and cost-effectiveness. We analysed the effect of monthly versus seasonal sampling frequencies on ecological lake status assessments. To this end, we extracted the values for the seasonal samplings directly from the monthly sampling frequency dataset, thus avoiding bias originating from different observers (Straile et al., 2013). However, when comparing phytoplankton assessments from different laboratories and countries it is obvious that sampling and analytical errors are important factors biasing phytoplankton counts (Rott, 1981).

We expected that monthly sampling would improve the precision of the average annual phytoplankton biovolume compared to seasonal sampling in Lake Mondsee. We found that annual biovolumes estimated 
from seasonal sampling were significantly higher than annual biovolumes estimated from monthly sampling. We conclude that this overestimation results from the overproportional effect of the phytoplankton spring peak on the estimated annual biomass derived from seasonal sampling. Higher annual variance in phytoplankton biovolume (resulting mainly from higherthan-usual spring peaks) resulted in higher estimates of the annual biovolume. Therefore, high spring values (relative to the rest of the year) are also affecting the calculated ecological status of lakes. This 'spring peak effect' is reduced if monthly instead of seasonal sampling frequency is applied. With respect to the WFD, the important implication is that phytoplankton biovolume estimates from lower sampling frequencies may negatively affect the ecological status assessment of lakes; this effect may be significant in lakes with seasonal strongly varying phytoplankton biomass. As Lake Mondsee did not reach the good ecological status requested by the WFD by 2008 , local authorities decided to increase the sampling frequency from four samples to 12 samples per year. In the following years, the ecological status of Lake Mondsee improved and even reached a high ecological status in 2014. Our analysis cautions against interpreting the improved water quality only in terms of the ongoing reoligotrophication process in Lake Mondsee (Dokulil \& Teubner, 2005). If the calculated EQR and corresponding $\mathrm{nEQR}$ values are close to the boundary conditions (e.g. 0.60 marking the transition from moderate to good ecological status), a lower sampling frequency may result in downgrading of the ecological status (Table 1). In spite of this caveat, major seasonal phytoplankton changes such as the transition from the spring peak to lower biomass in summer should be captured even with moderate sampling frequencies, provided that the sampling is adjusted according to the trophic status of the water bodies sampled (Abramic et al., 2012). In any case, average biovolumes derived from monthly and less frequent sampling should not be treated equally. The phytoplankton biovolume reference values for each ecological status may have to be adapted to account for the effect of sampling frequency. This is of particular importance if the ecological status of lakes is compared across different countries using different sampling strategies.
Changes of phytoplankton biovolume in the course of extreme events

Total phytoplankton biovolumes measured with FlowCAM were relatively low during the two heavy rain events in March 2015 and February 2016 (Fig. 3). This is not only because these episodes occurred early in the season. Cross et al. (2014) showed that a heavy precipitation event in a gravel pit lake led to an overall reduced phytoplankton biovolume but favoured small species such as cryptophytes, chlorophytes and centric diatoms. In seeming contrast, we observed that cryptophyte biovolumes decreased drastically during episodes of heavy rain. However, cryptophyte biovolumes recovered quickly within a week after the heavy rain events. Similarly, de Eyto et al. (2016) reported increased cryptophyte biovolumes only 3 days after an extreme precipitation event in an Irish humic lake. Some caution is needed when interpreting the dramatic reduction in cryptophyte biovolume in direct relation to the heavy rain events, as cryptophytes declined similarly over several consecutive sampling days on three other occasions that were not affected by heavy rain in 2016 (Fig. 4f). The quick decline and recovery of the cryptophyte populations may also result from active or passive downward dispersal of cryptophytes during the rain event to below $20 \mathrm{~m}$ depth and re-establishment of their original vertical distribution thereafter. Passive dispersal by windinduced turbulence to the upper hypolimnion is unlikely during summer when the lake is strongly stratified. However, we have no information on internal seiches in Lake Mondsee that may strongly affect the areal distribution of plankton abundance in stratified lakes (Gaedke \& Schimmele, 1991). Several common cryptophyte species perform (diel) vertical migrations in lakes (Sommer, 1985), and migration speeds up to $0.7 \mathrm{~m} \mathrm{~h}^{-1}$ have been measured (Arvola et al., 1991). These authors noted that cryptophyte cells were able to move quickly in response to environmental changes in the water column. In conclusion, there may have been no change at all in the cryptophyte biovolume integrated over the water column, but only a change in their relative vertical distribution during heavy rain events.

Episodes of heavy rain may also have long-term effects. This is because floods may reduce primary production due to increased water turbidity (Drakare et al., 2002; Jennings et al., 2012; Sadro \& Melack, 
2012), but they may also cause increased nutrient levels in the following months or even the next year, leading to a long-term increase in primary production (Kim et al., 2000; Foreman et al., 2004). In our study, we cannot judge upon the relative significance of these antagonistic effects.

Phosphorus is the limiting nutrient in Mondsee and most other European lakes (Jeppesen et al., 2005). Therefore, total phosphorus $\left(\mathrm{P}_{\mathrm{t}}\right)$ or SRP inputs into the lake should be estimated regularly, especially during and after heavy precipitation (Kerschbaumer, 2014). The $\mathrm{P}_{\mathrm{t}}$ load to Lake Mondsee can be calculated using various models (Strauss \& Staudinger, 2007; Klug \& Zeil, 2008). However, these models can only give a vague estimation of the true $P_{t}$ input, as they do not sufficiently take into account seasonal varying phosphorus sources from agricultural used land or snowmelt (Kerschbaumer, 2014; Klug et al., 2015). The measured SRP values were higher during the heavy rain event on 30 March 2015 compared to the heavy rain event on 02 February 2016. It is known that heavy rain events co-occurring with the snowmelt period and/or agricultural fertilisation (such as in March 2015) increase the $\mathrm{P}_{\mathrm{t}}$ input into water bodies (Strauss \& Staudinger, 2007; Jennings et al., 2012; Michalak et al., 2013; Schroth et al., 2015; Joung et al., 2017; Rosenberg \& Schroth, 2017). During the heavy rain event on 02 February 2016, the measured SRP concentrations within the lake and the tributaries were relatively low. This was because the heavy rain event occurred earlier in the year than the heavy rain event in 2015 , i.e. before the peak of the snowmelt and the beginning of the fertilisation period.

We demonstrated earlier that there were only minor changes within the phytoplankton community composition in the course of the 2015 heat wave (Bergkemper \& Weisse, 2017). The lake was strongly stratified during the period of the heat wave, with the epilimnion extending from the surface to 4-6 m, and the temperature remained constant below $6 \mathrm{~m}$ (Bergkemper \& Weisse, 2017). However, the heat wave led to significantly higher $P$. rubescens and chlorophyte biovolumes in Lake Mondsee. Our present study suggests that the average annual biovolume of $P$. rubescens was underestimated by $32 \%$ in 2015 , if the biovolumes derived from the heat wave samplings were not adequately considered. Although there is no obvious explanation for the increased biomass of $P$. rubescens during the heat wave, our work adds to the general conjecture that $P$. rubescens may directly or indirectly benefit from climate change and unusually warm summers (Posch et al., 2012; Gallina et al., 2017). In agreement with these observations, the annual average biovolume of $P$. rubescens in Lake Mondsee was $0.12 \mathrm{~mm}^{3} 1^{-1}$ in (the warmer year) 2015, compared to only $0.02 \mathrm{~mm}^{3} \mathrm{l}^{-1}$ in (the colder year) 2014 (Schafferer \& Pfister, 2016); phytoplankton data from the WFD monitoring in 2016 are not yet available. These findings seem to contradict Dokulil \& Teubner (2012), who concluded from data obtained during the period 1969-2010 that annual average biovolumes of $P$. rubescens in Lake Mondsee did not directly correspond to climate signals; these authors reported that $P$. rubescens only benefits from climate warming early in the year, during late spring overturn and early summer. However, these long-term studies cannot be compared directly to short-term observations derived from a 2-year period. More important in the context of the present study, the higher average biovolume of $P$. rubescens recorded in 2015 than in 2014 lead to a downgrading of the ecological status of the lake from high to good (Schafferer \& Pfister, 2016). Therefore, precise calculation of the average annual biomass of $P$. rubescens has practical implications for water management.

Chlorophyte biovolumes also increased significantly during the heat wave (Fig. 4c). When samples taken in the course of the heat wave were included, the average annual chlorophyte biovolume increased by $11 \%$. This is in accordance to previous studies showing that chlorophyte growth is promoted by increasing water temperatures (Lürling et al., 2013; Weisse et al., 2016). Although chlorophytes contributed only little to the total annual biovolume in Lake Mondsee, our findings may have more important implications for lakes with higher chlorophyte biomass.

Phytoplankton abundance and biovolume estimated by the different methods

Overall, inverted light microscopy and FlowCAM showed similar trends for phytoplankton abundance and biovolume (Fig. 4). However, FlowCAM estimates of large phytoplankton taxa were lower than microscopic estimates, as some large single cells and colonies (e.g. Ceratium hirundinella (O.F.Müller) Dujardin, P. rubescens filaments and Dinobryon sp. 
colonies,) were most probably sieved out using the $200 \mu \mathrm{m}$ mesh gauze prior to FlowCAM analyses. Secondly, the sampling volume processed by FlowCAM (1 ml) was low compared to light microscopic analyses (10-50 ml), further reducing the chances that rare species were caught by FlowCAM. In contrast, using FlowCAM higher cryptophyte, chlorophyte and coccal cyanobacterial biovolumes were estimated compared to inverted light microscopy and monthly sampling. Additionally, cell shrinkage due to Lugol's fixation may lead to an underestimation of cryptophyte cell volume (Menden-Deuer et al., 2001; Zarauz \& Irigoien, 2008; Bergkemper \& Weisse, 2017). Furthermore, sampling errors might have affected the results because the microscopic and FlowCAM counts that we compared (Fig. 4) were obtained by two different laboratories (Rott, 1981). However, as we compared phytoplankton at the class level, differences in phytoplankton species classification played no role. Our data also suggest that coccal cyanobacteria are not adequately captured using inverted microscopy and Lugol's fixation; with light microscopy, the average annual biomass of coccal cyanobacteria was lower by $\sim 70 \%$ than by FlowCAM measurements. According to our FlowCAM records, coccal cyanobacteria were among the dominant phytoplankton taxa in late summer/autumn in Lake Mondsee in the years 2015 and 2016 (Fig. 4g). Cyanobacterial biomass serves as a general indicator of eutrophication (Søndergaard et al., 2011) and is a proxy for potentially harmful algal blooms in lakes (Reynolds \& Walsby, 1975; Steinberg \& Hartmann, 1988; Dokulil \& Teubner, 2000; Paerl \& Huisman, 2009). Therefore, the taxonomic composition of colonial cyanobacteria deserves more attention than is the case in the current Austrian monitoring programme. FlowCAM or similar assessment methods could serve as quick, objective and easy-to-perform assessment methods for coccal cyanobacteria. Although the purchase of such equipment is costly, (semi-) automated assessment methods require less operator training and are less biased (semi-automated counts and classifications) than the traditional Utermöhl technique. Compared to light microscopy, FlowCAM and flow cytometry have the additional advantage that live samples can be measured (Sieracki et al., 1998; Personnic et al., 2009).

Picocyanobacteria that are commonly overlooked by inverted microscopy can be measured accurately by epifluorescence microscopy and flow cytometry (reviewed by Weisse, 1993; Callieri \& Stockner, 2002; Callieri, 2007). Measurements from acoustic flow cytometry that are available since April, 2015 (this study), confirmed previous flow cytometric estimates from Lake Mondsee and the seasonal distribution of picocyanobacteria with a major peak in summer (Crosbie et al., 2003). Because the Attune cytometer used in the present study contains three different lasers, we could increase the taxonomic resolution of picocyanobacteria, relative to the previous flow cytometric measurements from the lake (Crosbie et al., 2003), and identify 11 populations as single-celled cyanobacteria or microcolonies (Bergkemper \& Weisse, 2017). Cell numbers of filamentous cyanobacteria and larger colonies of coccoid cyanobacteria are underestimated because flow cytometers measure particles (i.e. they do not capture single cells in colonies and filaments). This has only a minor effect on total cell numbers, because phycoerythrin-rich, single-celled picocyanobacteria dominate by far throughout the year in L. Mondsee (Crosbie et al., 2003) and other oligo-mesotrophic lakes (Callieri, 2007; Personnic et al., 2009). However, the presence of doublets (i.e. cells in division) and microcolonies affects the average particle volume. The cell size of single-celled picocyanobacteria usually ranges from 0.5 to $1.5 \mu \mathrm{m}$ (reviewed by Stockner et al., 2000), yielding a typical cellular biovolume of $\sim 0.3-1.2 \mu \mathrm{m}^{3}$ (Takahashi et al., 1985, Søndergaard et al., 1991; Weisse \& Kenter, 1991; Weisse \& Mindl, 2002; Jezberová \& Komárková, 2007). Therefore, the average particle (= cell) volume that we assumed $\left(1 \mathrm{~m}^{3}\right)$ for our flow cytometric measurements presents a conservative estimate of the contribution of picocyanobacteria $(\sim 16 \%)$ to total phytoplankton biomass in Lake Mondsee. Although this is only a crude calculation, it is similar to previous estimates obtained from size-fractionated Chl-a concentrations during the years 2000 and 2001, when picoplankton contributed between $8 \%$ (in December) and $45 \%$ (during late September) to the total phytoplankton biomass in Lake Mondsee (Crosbie et al., 2003). The data obtained for L. Mondsee fall into the range known from similar lakes (reviewed by Callieri, 2007; Personnic et al., 2009).

Picocyanobacteria not only contribute significantly to total phytoplankton biomass and primary production in lakes (Weisse, 1993; Callieri \& Stockner, 2002; 
Callieri, 2007) they are also sensitive indicators of anthropogenic stressors such as eutrophication and heavy metal contamination (Munawar et al., 1987; Munawar \& Weisse, 1989; Munawar et al., 1995; Weisse \& Mindl, 2002). Therefore, ignoring picocyanobacteria in phytoplankton assessment is a(nother) flaw of the current WFD monitoring practise (see also Moss, 2008).

\section{Conclusion}

Extreme events like heat waves and heavy rain are often missed in routine monitoring programmes. In part, this is because heavy rain may coincide with strong wind when sampling aboard ship is dangerous. Automated sampling using moored platforms may overcome this problem (Pomati et al., 2011). Some phytoplankton classes or lower-ranked taxa may show immediate responses to extreme events. We demonstrated that $P$. rubescens and chlorophyte average annual biomass in Lake Mondsee were underestimated by 32 and $11 \%$, respectively, if the data obtained from frequent sampling during a heat wave were not considered. In contrast, cryptophyte annual biovolumes were overestimated only by $2-4 \%$ if samples from heavy rain events were not included. We conclude that extreme events may lead to speciesspecific changes in phytoplankton abundance and biomass that can significantly affect the annual averages.

To account for the effects of extreme events, more samples need to be processed without increasing the analytical time. To this end, inverted microscopy, which is still the most widespread method for phytoplankton assessments with high taxonomic resolution, should be replaced by semi-automatic optical techniques for selected taxa. To obtain a cost-effective and more precise estimate of phytoplankton biomass, we suggest to combine light microscopy for the analyses of large and/or rare species (e.g. P. rubescens, Ceratium hirundinella) with FlowCAM or similar imaging methods for abundant nano- and microphytoplankton species, and with flow cytometry for picophytoplankton.

Acknowledgements Open access funding provided by University of Innsbruck and Medical University of Innsbruck. We thank Peter Stadler, Kurt Mayrhofer and Johanna Schmidt for their assistance aboard ship and in the laboratory. We also appreciate Ellen Schafferer's advice on WFD phytoplankton assessments. Constructive comments from two anonymous reviewers on an earlier version of this manuscript are gratefully acknowledged. This study was partially financed by the Tiroler Wissenschaftsfonds (GZ: UNI-0404/1794).

Open Access This article is distributed under the terms of the Creative Commons Attribution 4.0 International License (http:// creativecommons.org/licenses/by/4.0/), which permits unrestricted use, distribution, and reproduction in any medium, provided you give appropriate credit to the original author(s) and the source, provide a link to the Creative Commons license, and indicate if changes were made.

\section{References}

Abramic, A., J. G. del Rio, N. Martínez-Alzamora \& J. Ferrer, 2012. Evaluation of the possibility for phytoplankton monitoring frequency reduction in the coastal waters of the Community of Valencia, in the scope of the Water Framework Directive. Marine Pollution Bulletin 64: 1637-1647.

Alfieri, L., L. Feyen, F. Dottori \& A. Bianchi, 2015. Ensemble flood risk assessment in Europe under high end climate scenarios. Global Environmental Change 35: 199-212.

Arle, J., V. Mohaupt \& I. Kirst, 2016. Monitoring of surface waters in Germany under the water framework directivea review of approaches, methods and results. Water 8: 217.

Arvola, L., A. Ojala, F. Barbosa \& S. Heaney, 1991. Migration behaviour of three cryptophytes in relation to environmental gradients: an experimental approach. British Phycological Journal 26: 361-373.

Beniston, M., D. B. Stephenson, O. B. Christensen, C. A. Ferro, C. Frei, S. Goyette, K. Halsnaes, T. Holt, K. Jylhä \& B. Koffi, 2007. Future extreme events in European climate: an exploration of regional climate model projections. Climatic Change 81: 71-95.

Benfield, M. C., P. Grosjean, P. F. Culverhouse, X. Irigoien, M. E. Sieracki, A. Lopez-Urrutia, H. G. Dam, Q. Hu, C. S. Davis, A. Hansen, C. H. Pilskaln, E. M. Riseman, H. Schultz, P. E. Utgoff \& G. Gorsky, 2007. RAPID: research on Automated Plankton Identification. Oceanography 20: 172-187.

Bergkemper, V. \& T. Weisse, 2017. Phytoplankton response to the summer 2015 heat wave-a case study from prealpine Lake Mondsee, Austria. Inland Waters 7: 88-99.

Blain, S., J. Guillou, P. Treguer, P. Woerther, L. Delauney, E. Follenfant, O. Gontier, M. Hamon, B. Leilde, A. Masson, C. Tartu \& R. Vuillemin, 2004. High frequency monitoring of the coastal marine environment using the MAREL buoy. Journal of Environmental Monitoring 6: 569-575.

Brettum, P., 1989. Algen als Indikatoren für die Gewässerqualität in norwegischen Binnenseen. Norsk Institutt for vannforskning, NIVA, Oslo: 1-102.

Callieri, C., 2007. Picophytoplankton in freshwater ecosystems: the importance of small-sized phototrophs. Freshwater Reviews 1: 1-28. 
Callieri, C. \& J. G. Stockner, 2002. Freshwater autotrophic picoplankton: a review. Journal of Limnology 61: 1-14.

Carstensen, J., 2007. Statistical principles for ecological status classification of Water Framework Directive monitoring data. Marine Pollution Bulletin 55: 3-15.

Carvalho, L., B. Dudley, I. Dodkins, R. Clarke, J. Jones, S. Thackeray \& S. Maberly, 2007. Phytoplankton Classification Tool (Phase 2). Final report (CEH Project Number: C03236), Scotland \& Northern Ireland Forum for Environmental Research, Edinburgh: 94.

Chavez, F. P., J. T. Pennington, R. Herlien, H. Jannasch, G. Thurmond \& G. E. Friederich, 1997. Moorings and drifters for real-time interdisciplinary oceanography. Journal of Atmospheric and Oceanic Technology 14: 1199-1211.

Crosbie, N. D., K. Teubner \& T. Weisse, 2003. Flow-cytometric mapping provides novel insights into the seasonal and vertical distributions of freshwater autotrophic picoplankton. Aquatic Microbial Ecology 33: 53-66.

Cross, I. D., S. McGowan, T. Needham \& C. M. Pointer, 2014. The effects of hydrological extremes on former gravel pit lake ecology: management implications. Fundamental and Applied Limnology 185: 71-90.

Culverhouse, P. F., R. Williams, B. Reguera, V. Herry \& S. González-Gil, 2003. Do experts make mistakes? A comparison of human and machine identification of dinoflagellates. Marine Ecology Progress Series 247: 5.

de Eyto, E., E. Jennings, E. Ryder, K. Sparber, M. Dillane, C. Dalton \& R. Poole, 2016. The response of a humic lake ecosystem to an extreme precipitation event: physical, chemical and biological implications. Inland Waters 6(4): 483-498.

Dixon, W. \& B. Chiswell, 1996. Review of aquatic monitoring program design. Water Research 30: 1935-1948.

Dokulil, M. T., 2014. Predicting summer surface water temperatures for large Austrian lakes in 2050 under climate change scenarios. Hydrobiologia 731: 19-29.

Dokulil, M. \& A. Jagsch, 1992. The effects of reduced phosphorus and nitrogen loading on phytoplankton in Lake Mondsee, Austria. Hydrobiologia 234(244): 389-394.

Dokulil, M. \& C. Skolaut, 1986. Succession of phytoplankton in a deep stratifying lake: Mondsee, Austria. Hydrobiologia 138: 9-24.

Dokulil, M. T. \& K. Teubner, 2000. Cyanobacterial dominance in lakes. Hydrobiologia 438: 1-12.

Dokulil, M. T. \& K. Teubner, 2005. Do phytoplankton communities correctly track trophic changes? An assessment using directly measured and palaeolimnological data. Freshwater Biology 50: 1594-1604.

Dokulil, M. T. \& K. Teubner, 2012. Deep living Planktothrix rubescens modulated by environmental constraints and climate forcing. Hydrobiologia 698: 29-46.

Dokulil, M., K. Schwarz \& A. Jagsch, 2000. Die Reoligotrophierung österreichischer Seen; Sanierung, Restuarierung und Nachhaltigkeit - Ein Überblick. Münchener Beiträge 53: 307-321.

Dokulil, M., K. Teubner \& M. Greisberger, 2005. Typenspezifische Referenzbedingungen für die integrierende Bewertung des ökologischen Zustandes stehender Gewässer Österreichs gemäß der EU-Wasserrahmenrichtlinie. Modul 1: Die Bewertung der Phytoplanktonstruktur nach dem Brettum-Index. Projektstudie Phase 3, Abschlussbericht.
Bundesministerium für Land- und Forstwirtschaft, Umwelt und Wasserwirtschaft, Wien: 49.

Domingues, R. B., A. Barbosa, H. Galvão, 2008. Constraints on the use of phytoplankton as a biological quality element within the Water Framework Directive in Portuguese waters. Marine Pollution Bulletin 56: 1389-1395

Drakare, S., P. Blomqvist, A.-K. Bergström \& M. Jansson, 2002. Primary production and phytoplankton composition in relation to DOC input and bacterioplankton production in humic Lake Örträsket. Freshwater Biology 47: 41-52.

EC, 2000. Directive of the European Parliament and of the Council 2000/60/EC, Establishing a Framework for Community Action in the Field of Water Policy p. 62.

Einsele, W., 1963. Am 31. März 1963 ging das Eis im Attersee unter! Österreichs Fischerei 16: 68-72.

European Environment Agency, 2017. Climate change, impacts and vulnerability in Europe 2016 EEA Report No 1/2017: 424.

Ficker, H., M. Luger \& H. Gassner, 2017. From dimictic to monomictic: empirical evidence of thermal regime transitions in three deep alpine lakes in Austria induced by climate change. Freshwater Biology 62: 1335-1345.

Findenegg, I., 1969. Die Eutrophierung des Mondsees im Salzkammergut. Zeitschrift für Wasser und Abwasserforschung 4: 139-144.

Foreman, C. M., C. F. Wolf \& J. C. Priscu, 2004. Impact of episodic warming events. Aquatic Geochemistry 10: 239-268.

Gallina, N., M. Beniston \& S. Jacquet, 2017. Estimating future cyanobacterial occurrence and importance in lakes: a case study with Planktothrix rubescens in Lake Geneva. Aquatic Sciences 79: 249-263.

Gaedke, U. \& M. Schimmele, 1991. Internal seiches in Lake Constance: influence on plankton abundance at a fixed sampling site. Journal of Plankton Research 13: 743-754.

Gieskes, W. W. C. \& G. W. Kraay, 1983. Dominance of Cryptophyceae during the phytoplankton spring bloom in the central North Sea detected by HPLC analysis of pigments. Marine Biology 75: 179-185.

Greisberger, S., M. T. Dokulil \& K. Teubner, 2008. A comparison of phytoplankton size-fractions in Mondsee, an alpine lake in Austria: distribution, pigment composition and primary production rates. Aquatic Ecology 42: 379-389.

Hamilton, D. P., 2014. A Global Lake Ecological Observatory Network (GLEON) for synthesising high-frequency sensor data for validation of deterministic ecological models. Inland Waters 4: 49-56.

Hering, D., A. Borja, J. Carstensen, L. Carvalho, M. Elliott, C. K. Feld, A.-S. Heiskanen, R. K. Johnson, J. Moe \& D. Pont, 2010. The European Water Framework Directive at the age of 10: a critical review of the achievements with recommendations for the future. Science of the total Environment 408: 4007-4019.

Hobro, R. \& Eva Willén, 1977. Phytoplankton countings. Intercalibration results and recommendations for routine work. Internationale Revue der gesamten Hydrobiologie und Hydrographie 62: 805-811.

IPCC, 2013. Climate Change 2013: The Physical Science Basis. Contribution of Working Group I to the Fifth Assessment Report of the Intergovernmental Panel on Climate Change. 
In Stocker, T. F., et al. (eds.), Sea level change. Cambridge University Press, Cambridge: 1535.

Jennings, E., S. Jones, L. Arvola, P. A. Staehr, E. Gaiser, I. D. Jones, K. C. Weathers, G. A. Weyhenmeyer, C.-Y. Chiu \& E. De Eyto, 2012. Effects of weather-related episodic events in lakes: an analysis based on high-frequency data. Freshwater Biology 57: 589-601.

Jeppesen, E., M. Søndergaard, J. P. Jensen, K. E. Havens, O. Anneville, L. Carvalho, M. F. Coveney, R. Deneke, M. T. Dokulil \& B. Foy, 2005. Lake responses to reduced nutrient loading-an analysis of contemporary long-term data from 35 case studies. Freshwater Biology 50: 1747-1771.

Jezberová, J. \& J. Komárková, 2007. Morphological transformation in a freshwater Cyanobium sp. induced by grazers. Environmental Microbiology 9: 1858-1862.

Jöhnk, K. D., J. E. F. Huisman, J. Sharples, B. E. N. Sommeijer, P. M. Visser \& J. M. Stroom, 2008. Summer heatwaves promote blooms of harmful cyanobacteria. Global Change Biology 14: 495-512.

Johnson, Z. I. \& A. C. Martiny, 2015. Techniques for Quantifying Phytoplankton Biodiversity. Annual Review of Marine Science 7: 299-324.

Kerschbaumer, M., 2014. Phosphorus surface runoff modeling after heavy rainfall events in the Mondsee catchment. Master Thesis. Paris Lodron University Salzburg.

Kim, B., K. Choi, C. Kim, U. H. Lee \& Y.-H. Kim, 2000. Effects of the summer monsoon on the distribution and loading of organic carbon in a deep reservoir, Lake Soyang, Korea. Water Research 34: 3495-3504.

Klug, H. \& P. Zeil, 2008. Spatially explicit modelling of phosphorus emissions. Geoinformatics 8: 32-35.

Klug, H., A. Kmoch \& S. Reichel, 2015. Adjusting the frequency of automated phosphorus measurements to environmental conditions. GI_Forum 2015. Journal for Geographic Information Science-Geospatial Minds Society 1: 590-599.

Lürling, M., F. Eshetu, E. J. Faassen, S. Kosten \& V. L. M. Huszar, 2013. Comparison of cyanobacterial and green algal growth rates at different temperatures. Freshwater Biology 58: 552-559.

Malmaeus, J. M., T. Blenckner, H. Markensten \& I. Persson, 2006. Lake phosphorus dynamics and climate warming: a mechanistic model approach. Ecological Modelling 190: $1-14$.

Menden-Deuer, S., E. J. Lessard \& J. Satterberg, 2001. Effect of preservation on dinoflagellate and diatom cell volume and consequences for carbon biomass predictions. Marine Ecology Progress Series 222: 41-50.

Michalak, A. M., E. J. Anderson, D. Beletsky, S. Boland, N. S. Bosch, T. B. Bridgeman, J. D. Chaffin, K. Cho, R. Confesor \& I. Daloğlu, 2013. Record-setting algal bloom in Lake Erie caused by agricultural and meteorological trends consistent with expected future conditions. Proceedings of the National Academy of Sciences USA 110: 6448-6452.

Mildner, J., M. Friedl \& M. Reichmann, 2011. Ergebnisbericht Qualitätselement Phytoplankton GZÜV 2010 Oberösterreich. KIS Kärntner Institut für Seenforschung $\mathrm{GmbH}$, Klagenfurt: 76-120.

Mildner, J., M. Friedl \& M. Reichmann, 2012. Ergebnisbericht Qualitätselement Phytoplankton GZÜV 2011
Oberösterreich. KIS Kärntner Institut für Seenforschung GmbH, Klagenfurt: 71-114.

Mildner, J., M. Friedl \& M. Reichmann, 2013. Ergebnisbericht Qualitätselement Phytoplankton GZÜV 2012 Oberösterreich. KIS Kärntner Institut für Seenforschung $\mathrm{GmbH}$, Klagenfurt: 70-111.

Montagnes, D. J. S., J. A. Berges, P. J. Harrison \& F. J. R. Taylor, 1994. Estimating carbon, nitrogen, protein, and chlorophyll a from volume in marine phytoplankton. Limnology and Oceanography 39: 1044-1060.

Moss, B., 2008. The Water Framework Directive: total environment or political compromise? Science of the Total Environment 400: 32-41.

Munawar, M., I. F. Munawar, P. E. Ross \& C. Mayfield, 1987. Differential sensitivity of natural phytoplankton size assemblages to metal mixture toxicity. Archiv für Hydrobiologie-Beiheft Ergebnisse der Limnologie/Advances in Limnology 25: 123-139.

Munawar, M., I. F. Munawar \& T. Weisse, 1995. Utility and applicability of autotrophic picoplankton as bioindicators of ecosystem health. In Munawar, M., O. Hanninen, N. Roy, N. Munawar, L. Karenlampi \& D. Bown (eds), Bioindicators of Environmental Health. SPB Academic Publishing, Amsterdam: 13-27.

Munawar, M. \& T. Weisse, 1989. Is the "microbial loop" an early warning indicator of anthropogenic stress? Hydrobiologia 188(189): 163-174.

Paerl, H. W. \& J. Huisman, 2009. Climate change: a catalyst for global expansion of harmful cyanobacterial blooms. Environmental Microbiology Reports 1: 27-37.

Pasztaleniec, A., 2016. Phytoplankton in the ecological status assessment of European lakes-advantages and constraints. Ochrona Srodowiska i Zasobów Naturalnych 27: 26-36.

Personnic, S., I. Domaizon, U. Dorigo, L. Berdjeb \& S. Jacquet, 2009. Seasonal and spatial variability of virio-, bacterio-, and picophytoplanktonic abundances in three peri-alpine lakes. Hydrobiologia 627: 99-116.

Pomati, F., J. Jokela, M. Simona, M. Veronesi \& B. W. Ibelings, 2011. An automated platform for phytoplankton ecology and aquatic ecosystem monitoring. Environmental Science \& Technology 45: 9658-9665.

Posch, T., O. Koster, M. M. Salcher \& J. Pernthaler, 2012. Harmful filamentous cyanobacteria favoured by reduced water turnover with lake warming. Nature Climate Change 2: 809-813.

R Core Team Development, 2011. R: A language and environment for statistical computing $\mathrm{R}$ Foundation for Statistical Computing. Austria, Vienna.

Rasconi, S., A. Gall, K. Winter \& M. J. Kainz, 2015. Increasing water temperature triggers dominance of small freshwater plankton. PLoS ONE 10: e0140449.

Rasconi, S., K. Winter \& M. J. Kainz, 2017. Temperature increase and fluctuation induce phytoplankton biodiversity loss-evidence from a multi-seasonal mesocosm experiment. Ecology and Evolution 7: 2936-2946.

Reynolds, C. S. \& A. E. Walsby, 1975. Water-blooms. Biological Reviews 50: 437-481.

Rigosi, A., C. C. Carey, B. W. Ibelings \& J. D. Brookes, 2014. The interaction between climate warming and eutrophication to promote cyanobacteria is dependent on trophic 
state and varies among taxa. Limnology and Oceanography 59: 99-114.

Rodriguez, F., M. Varela \& M. Zapata, 2002. Phytoplankton assemblages in the Gerlache and Bransfield Straits (Antarctic Peninsula) determined by light microscopy and CHEMTAX analysis of HPLC pigment data. Deep Sea Research Part II. Topical Studies in Oceanography 49: 723-747.

Rose, K. C., K. C. Weathers \& D. P. Hamilton, 2016. Insights from the Global Lake Ecological Observatory Network (GLEON). Inland Waters 6: 476-482.

Rosenberg, B. D. \& A. W. Schroth, 2017. Coupling of reactive riverine phosphorus and iron species during hot transport moments: impacts of land cover and seasonality. Biogeochemistry 132 : 103-122.

Rott, E., 1981. Some results from phytoplankton counting intercalibrations. Schweizerische Zeitschrift für Hydrologie 43: 34-62.

Sadro, S. \& J. M. Melack, 2012. The effect of an extreme rain event on the biogeochemistry and ecosystem metabolism of an oligotrophic high-elevation lake. Arctic, Antarctic, and Alpine Research 44: 222-231.

Schafferer, E. \& P. Pfister, 2014. Ergebnisbericht Qualitätselement Phytoplankton Oberösterreich 2013 GZÜV-Untersuchungen - Bewertung des ökologischen Zustandes gemäß EU-Wasserrahmenrichtlinie. ARGE Limnologie GesmbH, Innsbruck: 95-165.

Schafferer, E. \& P. Pfister, 2015. Ergebnisbericht Qualitätselement Phytoplankton Oberösterreich 2014 GZÜV-Untersuchungen - Bewertung des ökologischen Zustandes gemäß EU-Wasserrahmenrichtlinie. ARGE Limnologie GesmbH, Innsbruck: 95-166.

Schafferer, E. \& P. Pfister, 2016. Ergebnisbericht Qualitätselement Phytoplankton Oberösterreich 2015 GZÜV-Untersuchungen - Studie im Auftrag der Oberösterreichischen Landesregierung. ARGE Limnologie GesmbH, Innsbruck: 98-169.

Schroth, A. W., C. D. Giles, P. D. F. Isles, Y. Xu, Z. Perzan \& G. K. Druschel, 2015. Dynamic coupling of iron, manganese, and phosphorus behavior in water and sediment of shallow ice-covered eutrophic lakes. Environmental Science \& Technology 49: 9758-9767.

Sieracki, C. K., M. E. Sieracki \& C. S. Yentsch, 1998. An imaging-in-flow system for automated analysis of marine microplankton. Marine Ecology Progress Series 168: 285-296.

Skeffington, R., S. Halliday, A. Wade, M. Bowes \& M. Loewenthal, 2015. Using high-frequency water quality data to assess sampling strategies for the EU Water Framework Directive. Hydrology and Earth System Sciences 19: 2491-2504.

Sommer, U., 1985. Differential migration of Cryptophyceae in Lake constance. In Rankin, M. A. (ed.), Migration: mechanisms and adaptive significance. Contributions to marine science supplement. University of Texas, Austin: 166-175.

Søndergaard, M., L. M. Jensen \& G. Aertebjerg, 1991. Picoalgae in Danish coastal waters during summer stratification. Marine Ecology Progress Series 79: 139-149.

Søndergaard, M., S. E. Larsen, T. B. Jørgensen \& E. Jeppesen, 2011. Using chlorophyll a and cyanobacteria in the ecological classification of lakes. Ecological Indicators 11: 1403-1412.

Steinberg, C. E. W. \& H. M. Hartmann, 1988. Planktonic bloom-forming Cyanobacteria and the eutrophication of lakes and rivers. Freshwater Biology 20: 279-287.

Stockner, J., C. Callieri \& G. Cronberg, 2000. Picoplankton and other non-bloom forming cyanobacteria in lakes. In Whitton, B. A. \& M. Potts (eds.), The ecology of cyanobacteria. Kluwer Academic Publishers, Dordrecht: 195-231.

Stomp, M., J. Huisman, L. Vörös, F. R. Pick, M. Laamanen, T. Haverkamp \& L. J. Stal, 2007. Colourful coexistence of red and green picocyanobacteria in lakes and seas. Ecology Letters 10: 290-298.

Straile, D., M. C. Jochimsen \& R. Kümmerlin, 2013. The use of long-term monitoring data for studies of planktonic diversity: a cautionary tale from two Swiss lakes. Freshwater Biology 58: 1292-1301.

Strauss, P. \& B. Staudinger, 2007. Berechnung der Phosphor und Schwebstofffrachten zweier Hauptzubringer (Zellerache, Fuschlerache) des Mondsees. Schriftenreihe BAW 26: 18-33.

Takahashi, M., K. Kikuchi \& Y. Hara, 1985. Importance of picocyanobacteria biomass (unicellular, blue-green algae) in the phytoplankton population of the coastal waters off Japan. Marine biology 89: 63-69.

Tokar, J. M. \& T. D. Dickey, 2000. 13. Chemical sensor technology: current and future applications. Chemical Sensors. Oceanography 1: 303.

Utermöhl, H., 1958. Zur Vervollkommnung der quantitativen Phytoplankton-Methodik. Mitteilungen der internationalen Vereinigung für theoretische und angewandte Limnologie 9: 1-38.

van de Bund, W. \& A. G. Solimini, 2007. Ecological quality ratios for ecological quality assessment in inland and marine waters. Institute for Environment and Sustainability, Ispra: 24.

Vogler, P., 1966. Zur Analytik der Phosphorverbindungen in Gewässer. Limnologica 4: 437-444.

Vuorio, K., L. Lepistö \& A.-L. Holopainen, 2007. Intercalibrations of freshwater phytoplankton analyses. Boreal Environment Research 12: 561-569.

Weisse, T., 1993. Dynamics of autotrophic picoplankton in marine and freshwater ecosystems. Advances in Microbial Ecology 13: 327-370.

Weisse, T. \& U. Kenter, 1991. Ecological characteristics of autotrophic picoplankton in a prealpine lake. Internationale Revue der gesamten Hydrobiologie 76: 493-504.

Weisse, T. \& B. Mindl, 2002. Picocyanobacteria-sensitive bioindicators of contaminant stress in an alpine lake (Lake Traunsee, Austria). Water, Air, and Soil Pollution 2: 191-210.

Weisse, T., B. Gröschl \& V. Bergkemper, 2016. Phytoplankton response to short-term temperature and nutrient changes. Limnologica 59: 78-89.

Wolfram, G., K. Donabaum \& M. T. Dokulil, 2013. Guidance on the monitoring of the biological quality elements. Vienna: 76.

Wolfram, G., K. Donabaum \& M. Dokulil, 2015. Leitfaden zur Erhebung der biologischen Qualitätselements, Teil B2 Phytoplankton. Bundesministerium für Land- und 
Forstwirtschaft, Umwelt und Wasserwirtschaft Sektion IV, Wien: 76.

Wolfram, G., R. Niedermayr \& K. Donabaum, 2010. Bewertung des ökologischen Zustandes von 5 Seen in Oberöstereich anhand des Biologischen Qualitätselements Phytoplankton im Rahmen der GZÜV 2009. DWS Hydro-Ökologie GmbH Technisches Büro für Gewässerökologie und Landschaftsplanung, Wien: 23-54.

Wollschläger, J., A. Nicolaus, K. H. Wiltshire \& K. Metfies, 2014. Assessment of North Sea phytoplankton via molecular sensing: a method evaluation. Journal of Plankton Research 36: 695-708.

Wood, S. A., K. F. Smith, J. C. Banks, L. A. Tremblay, L. Rhodes, D. Mountfort, S. C. Cary \& X. Pochon, 2013. Molecular genetic tools for environmental monitoring of New Zealand's aquatic habitats, past, present and the future. New Zealand Journal of Marine and Freshwater Research 47: 90-119.
Xiao, X., H. Sogge, K. Lagesen, A. Tooming-Klunderud, K. S. Jakobsen, T. Rohrlack \& C Lovejoy, 2014. Use of high throughput sequencing and light microscopy show contrasting results in a study of phytoplankton occurrence in a freshwater environment. PLoS ONE 9(8): e106510.

Zarauz, L. \& X. Irigoien, 2008. Effects of Lugol's fixation on the size structure of natural nano-microplankton samples, analyzed by means of an automatic counting method. Journal of Plankton Research 30: 1297-1303.

[ZAMG] Zentralanstalt für Meteorologie und Geodynamik. 2017. Annual averages for the years 2015 and 2016 [available on internet at http://www.zamg.ac.at/cms/de/ klima/klimauebersichten/jahrbuch].

Znachor, P., E. Zapomělová, K. Řeháková, J. Nedoma \& K. Šmek, 2008. The effect of extreme rainfall on summer succession and vertical distribution of phytoplankton in a lacustrine part of a eutrophic reservoir. Aquatic Sciences 70: $77-86$. 